Abstracta Iranica Abstracta Iranica

Revue bibliographique pour le domaine irano-aryen

Volume 30 | 2010

Comptes rendus des publications de 2007

\title{
Sufism. The Formative Period. Berkeley / Los Angeles, The University of California Press, 2007, 202 p.
}

Ève Feuillebois-Piérunek

\section{Q OpenEdition}

1 Journals

Édition électronique

URL : http://journals.openedition.org/abstractairanica/37921

DOI : 10.4000/abstractairanica.37921

ISSN : 1961-960X

\section{Éditeur :}

CNRS (UMR 7528 Mondes iraniens et indiens), Éditions de l'IFRI

\section{Édition imprimée}

Date de publication : 8 avril 2010

ISSN : 0240-8910

\section{Référence électronique}

Ėve Feuillebois-Piérunek, «Sufism. The Formative Period. Berkeley / Los Angeles, The University of California Press, 2007, 202 p. », Abstracta Iranica [En ligne], Volume 30 | 2010, document 226, mis en ligne le 08 avril 2010, consulté le 26 septembre 2020. URL : http://journals.openedition.org/ abstractairanica/37921 ; DOI : https://doi.org/10.4000/abstractairanica.37921

Ce document a été généré automatiquement le 26 septembre 2020.

Tous droits réservés 


\title{
Sufism. The Formative Period. Berkeley / Los Angeles, The University of California Press, 2007, 202 p.
}

\author{
Ève Feuillebois-Piérunek
}

1 Durant les dernières décennies, de nombreuses études ont permis des avancées significatives dans la compréhension de la genèse du soufisme. Ce livre représente un essai de synthèse provisoire de cette période complexe, et s'appuie sur une approche historique de la question.

2 Les titres des six chapitres reflètent la progression des tendances mystiques de l'Islam du IX ${ }^{\mathrm{e}}$ au XII ${ }^{\mathrm{e}}$ siècle.

3 - Le soufisme bagdadien (étude de Kharrâz, Nûrî et Junayd essentiellement).

4 - Le soufisme au IX ${ }^{\mathrm{e}}$ siècle en Iraq (Tustârî), au Nord-Est de l'Iran (Malâmatis) et en Asie Centrale (Tirmidhî).

5 - Expansion du soufisme bagdadien.

6 - Formation d'une tradition soufie : essai de constitution d'un soufisme normatif aux $\mathrm{X}^{\mathrm{e}}$ et $\mathrm{XI}^{\mathrm{e}}$ siècles

$7 \quad$ - Formation de communautés soufies.

8 - Diffusion du soufisme dans toutes les dimensions de la vie sociale et culturelle en milieu urbain et dans les campagnes aux XI ${ }^{\mathrm{e}}$ et $\mathrm{XII}^{\mathrm{e}}$ siècles.

9 Selon l'A., des mouvements mystiques divers émergent de l'islam primitif : sans être totalement déconnectés, ils apparaissent indépendamment les uns des autres dans des régions et des environnements culturels différents : soufis d'Iraq, malâmatis d'Iran et « sages» de Transoxiane.

10 Les appellations "soufi » et "soufisme » sont au début uniquement associées aux groupes irakiens, liés à des communautés de renonçants et d'ascètes, alors que les malâmatis et sages, issus des classes d'artisans et de marchands, restent intégrés dans leurs sociétés. C'est pourtant le soufisme irakien qui deviendra prépondérant. La piété 
de type mystique, initialement répandue au sein d'une population urbaine éduquée de classe moyenne, deviendra ensuite plus populaire et se répandra dans toutes les couches de la société.

11 Un ouvrage stimulant qui jette une lumière nouvelle sur cette période, cruciale mais encore mal connue, de la genèse des mouvements mystiques en Islam. Certaines des thèses de l'A. devront cependant être confirmées par de nouvelles recherches.

INDEX

Thèmes : 8 . Soufisme

\section{AUTEURS}

ÈVE FEUILLEBOIS-PIÉRUNEK

Université Sorbonne Nouvelle-Paris III/Mondes iranien et indien 